\title{
IMPLEMENTATION OF GUIDED INQUIRY LEARNING MODEL ASSITED BY THREE TIER TEST ON CRITICAL THINKING
}

\author{
Sudirman, Halima, Muhammad Yusuf Hidayat,
}

Pendidikan Fisika Fakultas Tarbiyah dan Keguruan UIN Alauddin Makassar, sudirman.raja@uin-alauddin.ac.id

\begin{abstract}
Abstrak
Penelitian dilakukan untuk: mengetahui kemampuan berpikir kritis peserta didik sebelum dan setelah diajar dengan model pembelajaran guided inquiry berbantuan three tier test, mengetahui kemampuan berpikir kritis peserta didik sebelum dan setelah diajar dengan model pembelajaran direct instruction dan mengetahui perbedaan kemampuan berpikir kritis peserta didik yang diajar menggunakan model pembelajaran guided inquiry berbantuan three tier test dengan peserta didik yang diajar menggunakan model pembelajaran direct instruction. Jenis penelitian ini quasi eksperimen dengan desain nonequivalent control group design. Penelitian dilakukan di MAN Pinrang dengan populasi seluruh peserta didik kelas XI MIPA di MAN Pinrang. Jumlah sampel yang diambil sebanyak 22 peserta didik kelas kontrol (XI MIPA 1) dan 22 peserta didik kelas eksperimen (XI MIPA 2). Uji hipotesis menggunakan uji $\mathrm{t}$ dua sample independent dengan hasil penelitian menunjukkan bahwa uji hipotesis diperoleh nilai sign (2-tailed) sebesar 0,000. Karena nilai sign (2-tailed) $<0,05$ maka $\mathrm{H}_{0}$ ditolak dan $\mathrm{H}_{1}$ diterima. Sehingga dapat disimpulkan terdapat perbedaan kemampuan berpikir kritis peserta didik yang diajar menggunakan model pembelajaran guided inquiry berbantuan three tier test dengan yang diajar menggunakan model pembelajaran direct instruction kelas XI MIPA di MAN Pinrang.
\end{abstract}

\begin{abstract}
The study was conducted to: determine the critical thinking skills of students before and after being taught with the guided inquiry learning model assisted by three tier test, determine the critical thinking skills of students before and after being taught by the direct instruction learning model and determine the differences in the critical thinking skills of students who are taught using the direct instruction model guided inquiry learning model assisted by three tier test with students who are taught using direct instruction learning model. This type of research is a quasi-experimental design with a nonequivalent control group design. The study was conducted at MAN Pinrang with a population all students of class XI MIPA at MAN Pinrang. The number of samples taken was 22 students in the control class (XI MIPA 1) and 22 students in the experimental class (XI MIPA 2). Hypothesis testing using a two-sample independent $t$-test with the results showed that the hypothesis test obtained a sign value (2tailed) of 0,000. Because the sign value (2-tailed) $<0,05, H_{0}$ is rejected and $H_{1}$ is accepted. So we can be concluded there are differences in the critical thinking skills of students who are taught using the guided inquiry learning model assisted by three tier test with those taught using the direct instruction learning model for class XI MIPA at MAN Pinrang.
\end{abstract}

Keywords: guided inquiry, critical thinking skills, three tier test 


\section{Pendahuluan}

Undang-undang Republik Indonesia tentang Sistem Pendidikan Nasional memuat nilai-nilai luhur, moralitas, kecerdasan, dan keterampilan yang dibutuhkan diri sendiri, masyarakat, bangsa, dan negara untuk memperluas kemungkinan peserta didik dan memberikan kontribusi bagi perkembangan diri, masyarakat, bangsa, dan negara.

Pendidikan diharapkan mampu memberikan pengetahuan yang memungkinkan orang untuk mengatasi tugas-tugas profesional dan masalah dalam kehidupan sehari-hari. Namun, dalam kondisi kehidupan yang berubah dengan cepat saat ini, seringkali kita tidak dapat menerapkan pengetahuan yang kita miliki untuk memecahkan masalah yang muncul. Kita membutuhkan kemampuan untuk memperoleh, memilih, dan mengelola informasi untuk bertahan dalam lingkungan yang kompetitif, tidak pasti, dan terus berubah. Maka diperlukan sebuah kemampuan, yaitu kemampuan berpikir kritis.

Keberhasilan dalam mencapai tujuan pendidikan tergantung pada proses pembelajaran, yang menjadi tanggung jawab guru sebagai pendidik. Pendidik harus mampu mengubah cara berpikir peserta didik, kemampuannya, dan membantu peserta didik untuk selalu memanfaatkan kesempatan belajar yang beragam dari berbagai sumber dan media. Salah satu permasalahan dalam proses pembelajaran fisika di pendidikan formal (sekolah) adalah rendahnya kemampuan berpikir kritis peserta didik. Kemampuan berpikir kritis yang rendah akan mempengaruhi hasil belajar peserta didik.

Penelitian yang dilakukan oleh Nyoman dalam jurnal Saminan (2016:2) menyatakan bahwa peserta didik yang mengikuti model pembelajaran inkuiri memiliki perbedaan kemampuan berpikir kritis dan kemampuan ilmiah.

Kemampuan berpikir kritis harus diterapkan dalam pembelajaran fisika untuk memperoleh fakta dengan mempelajari pengetahuan konseptual sehingga mudah dipahami dan diterapkan dalam kehidupan sehari-hari, atau dapat memperoleh pemikiran yang lebih berkualitas dengan mempelajari pengetahuan prosedural, sehingga dapat mengintegrasikan fakta tersebut.

Dalam Islam, manusia memiliki kebebasan berpikir dan berkeinginan, dan dalam proses kebebasan tersebut manusia dapat memiliki pikiran dan kepribadian yang sempurna, serta dapat berpikir dengan benar. Sebagaimana Allah swt. berfirman dalam Al-Qur'an surah $\mathrm{Al}$ Hasyr ayat 21

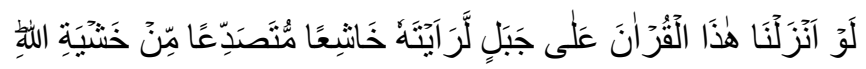

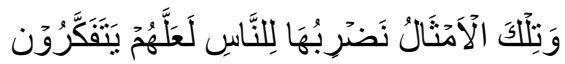

Terjemahan:

"Sekiranya kami turunkan Al-qur'an ini pada sebuah gunung, pasti kamu akan melihatnya tunduk terpecah belah disebabkan takut kepada Allah dan perumpamaanperumpamaan itu kami buat untuk manusia agar mereka berpikir.(Q.S Al-Hasyr:21)

Ayat diatas menyeru agar manusia itu berpikir tentang kebesaran Allah SWT atas apa-apa yang diciptakan di langit dan bumi. Oleh karena itu Allah SWT menyadarkan hati manusia supaya manusia tunduk kepada-Nya.

Dalam proses belajar mengajar di sekolah peserta didik tidak hanya berperan sebagai penerima informasi melainkan bertindak sebagai pusat informasi hal ini bisa terjadi ketika pendidik mampu menentukan model pembelajaran yang dapat membantu peserta didik memiliki dua peran dalam proses pembelajaran yakni sebagai pusat informasi dan penerima informasi.

Menurut Yazidi (2014: 3) Rusman dalam bukunya yang berjudul Model-Model Pembelajaran Mengembangkan Profesionalisme Pendidik mengemukakan bahwa pada model pembelajaran perlu adanya suatu rencana, pola pembelajaran jangka panjang yang digunakan untuk membentuk kurikulum, membuat rancangan bahan pembelajaran serta membimbing proses pembelajaran di kelas.

Partah (2017: 19) berpendapat bahwa untuk mendeskripsikan realisasi model pembelajaran Joyce, B. et al. Mereka mengusulkan empat konsep yang disebut sebagai komponen model pembelajaran dan terdiri dari sintaks, sistem sosial, prinsip reaksi, dan sistem pendukung . Dampak pembelajaran tidak termasuk dalam komponen pembelajaran, karena keterampilan berbasis aktivitas dapat langsung dirancang untuk menentukan dampak model pembelajaran. Joyce, B. et al., membagi pengaruh pembelajaran guided inquiry menjadi dua jenis, yaitu dampak instruksional dan dampak pengiring.

Mandagi dan Arintje ( 2017) dalam bukunya yang berjudul Model dan Rancangan Pembelajaran mengemukakan bahwa model pembelajaran inkuiri merupakan model pembelajaran yang berbasis konstruktivisme. Barlet percaya bahwa pada pendekatan konstruktivisme ini peserta didik mengkonstruksi pandangannya sendiri atau setidaknya menafsirkan berdasarkan persepsinya secara terstruktur mengenai pengalaman dan keyakinan yang dimiliki orang sebelumnya dan digunakan untuk menafsirkan objek atau peristiwa. 
Konstruktivisme merupakan sudut pandang dalam pembelajaran yang menganggap bahwa dalam proses belajar peserta didiklah yang membentuk pengetahuannya sendiri untuk memahami teori sesuai yang diamati. Pendidik hanya berperan sebagai pendamping dalam pembelajaran yang membantu peserta didik untuk membangun pengetahuannya sendiri.

Menurut Sanjaya (2006: 259) model pembelajaran konvensional yang dikemukakan oleh Sanjaya bahwa dalam pembelajaran konvensional, peserta didik memposisikan diri sebagai objek belajar dan bertindak sebagai penerima informasi yang pasif. Oleh karena itu, secara umum metode pengajarannya adalah ceramah, tanya jawab, dan pekerjaan rumah.

Jusman (2020: 23) berpendapat bahwa model inquiry dikembangkan dengan beberapa model antara lain inkuiri bebas atau free inquiry, inquiri terbimbing atau guided inquiry, dan modified free inquiry atau inkuiri bebas termodifikasi.

Dalam proses pembelajaran terkadang peserta didik hanya berperan sebagai penerima informasi dimana pendidiklah yang bertindak sebagai pusat informasi. Model pembelajaran yang sesuai dengan proses pembelajaran ini yaitu model pembelajaran konvensional.

Sanjaya (2006:259) mengemukakan bahwa dalam model pembelajaran konvensional, peserta didik memposisikan diri sebagai objek belajar dan bertindak sebagai penerima informasi yang pasif. Oleh karena itu, secara umum metode pengajarannya adalah ceramah, tanya jawab, dan pekerjaan rumah.

Ruseffendi dalam jurnal Ibrahim (2017: 23) mengemukakan bahwa pembelajaran tradisional atau konvensional memiliki karakteristik tertentu secara keseluruhan, seperti menekankan pada kemampuan mengingat daripada memahami, menekankan keterampilan menghitung, menekankan hasil, proses, dan pengajaran yang berpusat pada pendidik.

Menurut Hunaepi, dkk, (2014: 56) direct instruction adalah suatu model pembelajaran yang pemusatannya pada pendidik yang disajikan dalam 5 tahap yaitu; penyampaian tujuan pembelajaran, menampilkan pengetahuan dan keterampilan, memberi latihan terbimbing, mengecek pemahaman, memberikan umpan balik, memberikan penyuluhan dan transfer ilmu.

Santrock (2007: 309) berpendapat bahwa berdasarkan semua pendekatan konstruktivis pengetahuan disusun oleh peserta didik. Dimana pendekatan konstruktivis mengutamakan hubungan sosial dalam pengajaran dan pemahaman dibangun bersamaan dengan melibatkan orang lain.
Pendekatan ini dapat memberikan peluang bagi peserta didik untuk menilai dan meluruskan konsep serta ilmu mereka ketika bertukar pemikiran dengan peserta didik lain pada saat berpartisipasi mencari pengetahuan secara bersamaan. Dengan adanya pendekatan konstruktivis dalam pembelajaran dapat membantu peserta didik membangun pengetahuannya sendiri.

Penelitian Nisa (2017) menyimpulkan bahwa model pembelajaran inkuiri terbimbing efektif meningkatkan kemampuan berpikir kritis peserta didik. Hal ini didukung oleh penelitian Tyler yang menemukan bahwa pembelajaran memberikan kesempatan kepada peserta didik untuk memperoleh keterampilan pemecahan masalah dapat meningkatkan keterampilan berpikir kritis.

Lismaya (2019:7-10) dalam bukunya berjudul Berpikir Kritis dan PBL(Problem Based Learning) Norris dan Ennis menunjukkan bahwa berpikir kritis merupakan berpikir logis dan reflektif yang berfokus pada pengambilan keputusan tentang apa yang akan dilakukan atau diyakini. Berpikir logis berarti berpikir yang didasarkan pada fakta-fakta untuk menghasilkan keputusan yang terbaik, sedangkan berpikir reflektif artinya secara sadar mencari dan menemukan solusi yang terbaik.

Menurut teori Ennis indikator keterampilan berpikir kritis terdiri dari lima keterampilan dasar yang disajikan pada tabelberikut:

Tabel 1. Indikator Kemampuan Berpikir Kritis

No. Indikator Kata-kata operasional

\begin{tabular}{lllr} 
1. & $\begin{array}{l}\text { Memberikan } \\
\text { penjelasan } \\
\text { sederhana }\end{array}$ & $\begin{array}{l}\text { Menganalisis } \\
\text { mengajukan dan menjawab }\end{array}$ & $\begin{array}{r}\text { pertanyaan, } \\
\text { mertanyaan klarifikasi. }\end{array}$ \\
\hline 2. & Membangun & Mempertimbangkan kredibilitas \\
& keterampilan & suatu sumber, & melakukan \\
& dasar & $\begin{array}{l}\text { observasi } \\
\text { mempertimbangkan }\end{array}$ & hasil \\
& & observasi. & \\
\end{tabular}

\begin{tabular}{lll}
\hline 3. & $\begin{array}{l}\text { Penarikan } \\
\text { kesimpulan }\end{array}$ & $\begin{array}{l}\text { Mendeduksi dan menilai } \\
\text { deduksi menginduksi dan } \\
\text { menilai induksi, menilai } \\
\text { penilaian berharga. }\end{array}$ \\
\hline 4. & $\begin{array}{l}\text { Membuat } \\
\text { penjelasan } \\
\text { lebih lanjut }\end{array}$ & $\begin{array}{l}\text { Mendefinisikan istilah, menilai } \\
\text { definisi mengidentifikasikan } \\
\text { asumsi, }\end{array}$ \\
\hline 5. & $\begin{array}{l}\text { Mengatur } \\
\text { strategi dan } \\
\text { taktik }\end{array}$ & $\begin{array}{l}\text { Memutuskan sebuah tindakan } \\
\text { dan berinteraksi dengan orang } \\
\text { lain. }\end{array}$
\end{tabular}

Nitko \& Brookhart dalam jurnal Iskandar (2018: 13) berpendapat bahwa, tes didefinisikan sebagai alat atau program sistematis yang menggunakan skala numerik atau skema klasifikasi untuk mengamati dan menafsirkan satu atau lebih karakteristik seorang peserta didik. Untuk 
mengetahui kemampuan berpikir kritis peserta didik digunakan tes diagnostik berupa three tier test.

Menurut Arikunto (2006:34) Tes diagnostik adalah tes yang banyak digunakan untuk mengungkap kelemahan peserta didik sehingga diberikan penanganan yang tepat. Salah satu kelemahan peserta didik dalam menjawab soal adalah memiliki ide atau konsep yang salah dan tidak mengetahui konsep. Untuk menemukan strategi ketidakmampuan belajar, terlebih dahulu mencari tahu alasan kesulitan-kesulitan peserta didik.

Berdasarkan teori di atas tes merupakan alat yang digunakan untuk mengukur kemampuan peserta didik dalam menafsirkan fenomena gejala alam sesuai dengan fakta yang ada. Dalam penafsiran ini diperlukan suatu kemampuan yakni kemampuan berpikir kritis. Kemampuan berpikir kritis merupakan kemampuan untuk memperoleh fakta sesuai dengan konsep yang dipelajari yang sesuai dengan pengetahuan yang dimiliki oleh peserta didik. Untuk mengetahui sejauh mana kemampuan berpikir kritis peserta didik maka diperlukan tes diagnostik, dimana tes diagnostik ini digunakan untuk mengetahui kelemahan peserta didik dalam berpikir kritis, sehingga dapat diberikan penangan yang sesui setelah mengetahui kelemahan tersebut.

Dari hasil wawancara peneliti dengan Ibu Andi Nurmalasari, S.Pd selaku guru mata pelajaran fisika di MAN Pinrang. Ia mengatakan bahwa beberapa peserta didik tidak mengajukan pertanyaan terkait materi yang mereka pelajari di kelas saat guru sedang mengajar. Hanya beberapa peserta didik yang dapat mengajukan pertanyaan sendiri atas pertanyaan yang diajukan selama proses pembelajaran. Peserta didik belum bisa memberikan argumentasi atas pendapat yang diberikan sehingga dapat dipahami oleh peserta didik lain, hanya sebagian peserta didik yang mampu mengembangkan ide-ide atau argumentasi yang diberikan dari peserta didik lain. Dalam proses pembelajaran, peserta didik seringkali pasif, dan sebagian dari mereka tidak mampu mengembangkan ide dan argumen terkait dengan materi pembelajaran. Mengingat pentingnya peningkatan kemampuan berpikir kritis peserta didik, maka perlu adanya peningkatan kualitas proses pembelajaran. Melalui model pembelajaran guided inquiry, dapat membantu peserta didik yang belum terbiasa dengan pembelajaran berbasis masalah dalam mengembangkan kemampuan berpikir kritis.

Salah satu upaya yang dapat dilakukan dalam pembelajaran fisika adalah dengan menggunakan model pembelajaran inkuiri dalam hal ini model pembelajaran guided inquiry. Untuk menilai kemampuan berpikir kritis fisika, diperlukan alat bantu berupa soal three tier test atau tes tiga tingkat untuk memahami seperti apa kemampuan berpikir kritis peserta didik dan apakah ada perubahan kemampuan berpikir kritis peserta didik setelah menerapkan model tersebut.

Berdasarkan uraian tersebut maka dilakukan penelitian dengan tujuan untuk mengetahui perbedaan kemampuan berpikir kritis peserta didik yang diajar menggunakan model pembelajaran guided inquiry berbantuan three tier test dengan peserta didik yang diajar menggunakan model pembelajaran direc instruction kelas XI MIPA di MAN Pinrang.

\section{Metode}

Dalam penelitian ini digunakan jenis penelitian quasi eksperimen dengan desain Nonequivalent Control Group Design.

Sampel penelitian ini yaitu kelas XI MIPA 1 dan XI MIPA 2 yang dipilih menggunakan teknik purposive sampling. Teknik purposive sampling merupakan teknik pengambilan sampel dalam penelitian menggunakan pertimbangan atau kriteria tertentu.

Jumlah sampel yang digunakan yaitu 22 peserta didik kelas kontrol (XI MIPA 1) dan 22 peserta didik kelas eksperimen (XI MIPA 2). Dimana kelas eksperimen diberikan perlakuan dalam bentuk implementasi model pembelajaran guided inquiry berbantuan three tier test.

Instrumen yang digunakan dalam penelitian ini yaitu soal uraian three tier test, rancangan perangkat pembelajaran (RPP), lembar observasi, lembar kerja peserta didik (LKPD) dan angket respon peserta didik.

Teknik analisis data dalam penelitian ini yaitu analisis deskriptif menggunakan tabel distribusi frekuensi dan pengkategorian kemampuan berpikir krtitis peserta didik dan analisis inferensial menggunakan uji nosrmalitas, uji homogenitias dan uji hipotesis. Uji hipotesis yang digunakan adalah uji $\mathrm{t}$ dua sample independent dengan kriteria penarikan kesimpulan yaitu jika $t_{\text {hitung }}>\mathrm{t}_{\text {tabel }}$ maka $H_{0}$ ditolak. Jika $\mathrm{t}_{\text {hitung }}<$ tabel maka $H_{0}$ diterima, dengan taraf signifikan $\alpha=$ 0,05(Siregar, 2014:199). 


\section{Hasil dan Pembahasan}

a. Hasil Analisis Kemampuan Berpikir Kritis Peserta Didik Sebelum dan Setelah Diterapkan Model Pembelajaran Guided Inquiry berbantuan Three Tier Test terhadap Kemampuan Berpikir Kritis Peserta Didik Kelas XI MIPA di MAN Pinrang

Hasil analisis deskriptif kemampuan berpikir kritis peserta didik sebelum dan setelah diberikan perlakuan dari kelas eksperimen (XI MIPA 2) dapat disajikan dalam tabel berikut:

Tabel 4: Statistik deskriptif kemampuan berpikir kritis kelas eksperimen (XI MIPA 2)

\begin{tabular}{ccc}
\hline \multirow{2}{*}{$\begin{array}{c}\text { Statistik } \\
\text { deskriptif }\end{array}$} & \multicolumn{2}{c}{ Nilai Statistik } \\
\cline { 2 - 3 } & Pretest & Posttest \\
\hline $\mathbf{N}$ & 22 & 22 \\
\hline Maksimum & 56 & 92 \\
\hline Minimum & 27 & 62 \\
\hline Mean & 40,13 & 76,5 \\
\hline Standar deviasi & 7,79 & 8,95 \\
\hline Variansi & 60,79 & 80,16
\end{tabular}

Nilai maksimum kemampuan berpikir kritis peserta didik sebelum diterapkan model adalah 56 dan nilai minimum adalah 27. Rata-rata nilai yang diperoleh sebesar 40,13 dengan standar deviasi 7,79. Sedangkan nilai maksimum kemampuan berpikir kritis peserta didik setelah diterapkan model pembelajaran adalah 92 dan nilai minimum adalah 62. Rata-rata nilai yang diperoleh sebesar 76,5 dengan standar deviasi 8,95.

Dari hasil analisis deskriptif yang diperoleh maka kategorisasi kemampuan berpikir kritis peserta didik sebelum dan dan setelah diberikan perlakuan dapat disajikan grafik histogram kategorisasi berikut ini:

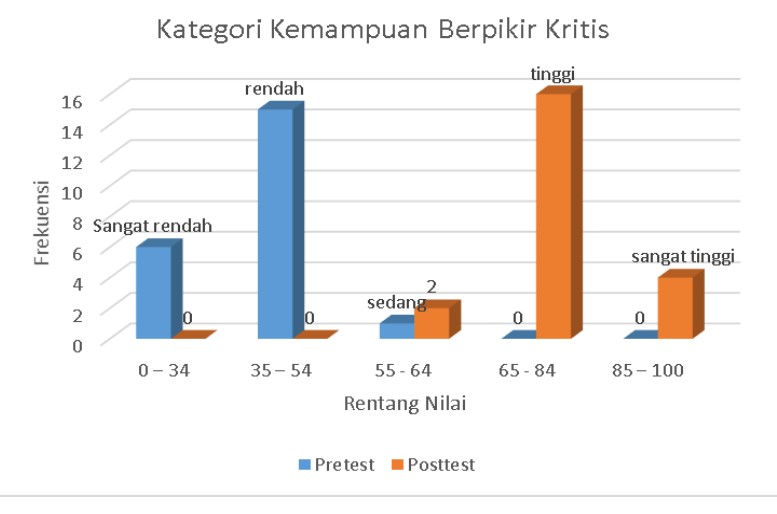

Gambar 1: Grafik Histogram Kemampuan Berpikir Kritis Kelas XI MIPA 2

Dari gambar 1 di atas diperoleh sebaran nilai kemampuan berpikir kritis peserta didik kelas eksperimen sebelum diterapkan model pembelajaran guided inquiry berbantuan three tier test peserta didik berada pada kategori sangat rendah dengan sebanyak 6 orang, kategori rendah terdapat 15 orang dan terdapat 1 orang peserta didik yang berada pada kategori sedang. Sedangkan setelah diterapkan model pembelajaran guided inquiry peserta didik berada pada kategori sangat tinggi terdapat 4 orang, kategori tinggi terdapat 16 orang peserta didik dan kategori sedang terdapat 2 orang peserta didik.

Sebelum diterapkan model pembelajaran guided inquiry, kemampuan berpikir kritis peserta didik berada pada kategori rendah, sangat rendah dan sedang. Nilai rata-rata peserta didik sebelum menerapkan model pembelajaran ini rendah karena materi yang diujikan belum diajarkan kepada peserta didik dan mereka menjawab pertanyaan berdasarkan pemahaman mereka sendiri. Hal ini bisa dilihat dari hasil menjawab soal pretest oleh peserta didik, dimana peserta didik cenderung menjawab soal pada tingkatan pertama kurang sesuai dengan teori, dan tingkatan kedua alasan menjawab kurang sesuai dengan teori serta tingkat keyakinan masih tidak yakin.

Peran pendidik sebagai motivator jelas 奶rlihat saat pendidik mengajak peserta didik untuk mengidentifikasi dan merumuskan masalah. Sebagai fasilitator pendidik memberi ruang kepada peserta didik melakukan percobaan, mengumpulkan data, melakukan tanya jawab dan memberi kesempatan peserta didik memaparkan hasil diskusinya. Pada setiap percobaan peserta didik memperoleh kecakapan dalam melakukan percobaan baik itu pada percobaan karakteristik gelombang maupun percobaan gelombang pada tali.

Dalam penelitian ini digunakan alat bantu three tier test untuk mengetahui kemampuan berpikir kritis peserta didik. Three tier test merupakan tes yang memiliki tiga tingkatan, tingkatan pertama adalah menanyakan pengetahuan peserta didik tentang konsep dari pilihan ganda. Tingkatan kedua adalah penalaran peserta didik dari proses menjawab pada tingkatan pertama. Tingkatan ketiga adalah pertanyaan mengenai keyakinan peserta didik tentang jawaban tingkatan pertama dan kedua (Septi, 2016:23).

Setelah diberikan perlakuan berupa implementasi model pembelajaran guided inquiry berbantuan three tier test kemampuan berpikir kritis peserta didik mengalami peningkatan yaitu berada 
pada kategori sangat tinggi, tinggi dan sedang. Peserta didik pada saat menjawab soal three tier test cenderung berada pada kategori tingkatan pertama menjawab benar, sesuai dengan teori, dan tingkatan kedua alasan menjawab kurang tepat dengan teori serta tingkat keyakinan yaitu yakin. Sehingga dapat disimpulkan bahwa kemampuan berpikir kritis peserta didik sebelum dan setelah diterapkan model pembelajaran guided inquiry berbantuan three tier test mengalami peningkatan secara signifikan.

Hasil penelitian ini sejalan dengan penelitian yang dilakukan oleh Rulita Niana, dkk (2016:605) yang menyatakan bahwa penerapan model pembelajaran inkuiri terbimbing pada pembelajaran fisikadapat meningkatkan sikap ilmiah dan kemampuan analisis peserta didik.

Demikian pula penelitian yang dilakukan oleh Christensenia Seranica, dkk (2018:28) menunjukkan bahwa model inkuiri terbimbing berpengaruh signifikan terhadap keterampilan berpikir kritis peserta didik.

Begitupun penelitian yang dilakukan oleh Nurhasan Ropií, dkk (2018:63) menyatakan bahwa penerapan model pembelajaran inkuiri terbimbing berbantuan media gores dapat melatih dan meningkatkan kemampuan berpikir kritis peserta didik pada konsep gerak linear.

Yang membedakan penelitian ini dengan penelitian sebelumnya adalah hasil penelitian sebelumnya menggunakan model pembelajaran inkuiri terbimbing menunjukkan bahwa model pembelajaran inkuiri terbimbing dapat meningkatkan kemampuan analisis dan sikap ilmiah peserta didik sedangkan dalam penelitian ini implementasi model pembelajaran inkuiri terbimbing terhadap kemampuan berpikir kritis peserta didik menunjukkan bahwa kemampuan berpikir kritis peserta didik setelah diberikan perlakuan mengalami peningkatan secara signifikan.

b. Analisis Kemampuan Berpikir Kritis Peserta Didik Sebelum dan Setelah Diterapkan Model Pembelajaran Direct Instruction terhadap Kemampuan Berpikir Kritis Peserta Didik Kelas XI MIPA di MAN Pinrang

Hasil analisis deskriptif kemampuan berpikir kritis peserta didik sebelum dan setelah diberikan perlakuan dari kelas kontrol (XI MIPA 1) dapat disajikan dalam tabel berikut:

Tabel 5: Statistik deskriptif kemampuan berpikir kritis kelas eksperimen (XI MIPA 2)

\begin{tabular}{ccc}
\hline Statistik & \multicolumn{2}{c}{ Nilai Statistik } \\
\cline { 2 - 3 } Deskriptif & Pretest & Posttest \\
\cline { 2 - 3 } N & 22 & 22 \\
\hline Maksimum & 41 & 84 \\
\hline Minimum & 11 & 16 \\
\hline Mean & 27,72 & 44,81 \\
\hline Standar deviasi & 9,17 & 12,86 \\
\hline Variansi & 84,20 & 165,39
\end{tabular}

Berdasarkan tabel di atas, nilai maksimum kemampuan berpikir kritis peserta didik sebelum diterapkan model adalah 41 dan nilai minimum adalah 11. Nilai rata-rata yang diperoleh sebesar 27,72 dengan standar deviasi 9,17. Sedangkan nilai maksimum kemampuan berpikir kritis peserta didik setelah diterapkan model pembelajaran adalah 84 dan nilai minimum adalah 16. Rata-rata yang diperoleh sebesar 44,81 dengan standar deviasi 12,86 dan variansi 165,39.

Dari hasil analisis deskriptif yang diperoleh maka kategorisasi kemampuan berpikir kritis peserta didik sebelum dan dan setelah diberikan perlakuan dapat disajikan grafik histogram kategorisasi berikut ini:

\section{Kemampuan Berpikir Kritis}

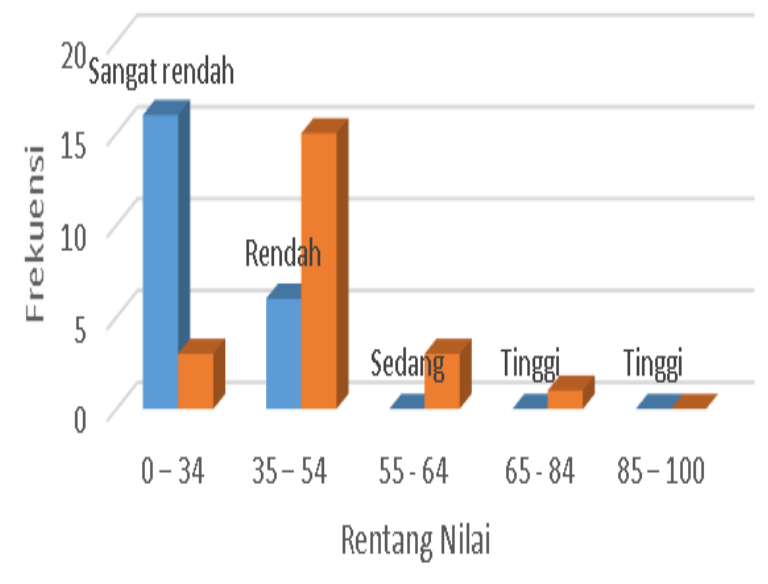

- Pretest Postest

Gambar 2: Grafik Histogram Kemampuan Berpikir Kritis Kelas XI MIPA 1

Dari grafik histogram di atas diperoleh sebaran nilai kemampuan berpikir kritis peserta didik kelas kontrol sebelum diterapkan model pembelajaran peserta didik yang berada pada kategori sangat rendah terdapat 16 orang dan 
terdapat 6 orang peserta didik yang berada pada kategori rendah. Sedangkan setelah diterapkan model pembelajaran peserta didik yang berada pada kategori sangat rendah terdapat 3 orang, kategori rendah terdapat 15 orang peserta didik, kategori sedang terdapat 3 orang peserta didik dan kategori tinggi terdapat 1 orang peserta didik

Sebelum diterapkan model pembelajaran direct instruction kemampuan berpikir kritis peserta didik pada kelas kontrol berada pada kategori rendah dan kategori sangat rendah. Nilai rata-rata peserta didik sebelum menerapkan model pembelajaran ini rendah karena materi yang diujikan tidak diajarkan kepada peserta didik dan mereka menjawab pertanyaan berdasarkan pemahaman mereka sendiri. Hal ini bisa dilihat dari hasil menjawab soal pretest oleh peserta didik, dimana peserta didik cenderung menjawab soal pada tingkatan pertama kurang sesuai dengan teori, dan tingkatan kedua alasan menjawab kurang sesuai dengan teori serta tingkat keyakinan masih tidak yakin.

Dalam menerapkan model pembelajaran direct instruction, pada saat pembelajaran berlangsung pendidik memberikan bahan materi kepada peserta didik yang kemudian peserta didik mencari sendiri dan mempresentasikan hasil temuannya kepada peserta didik lain, namun dalam diskusi tersebut peserta didik hanya sebatas menyampaikan materi, hanya terdapat beberapa peserta didik yang berani memberikan pertanyaan, sehingga proses pembelajaran cenderung pasif dan peserta didik lain hanya sekedar menyimak materi pembelajaran.

Setelah diberikan perlakuan berupa model pembelajaran direct instruction kemampuan berpikir kritis peserta didik berada pada kategori tinggi, sedang dan rendah. Berdasarkan rata-rata nilai peserta didik yang diperoleh menunjukkan bahwa terdapat perbedaan kemampuan berpikir kritis peserta didik sebelum dan setelah diajar menggunakan model pembelajaran direct instruction, namun peningkatan kemampuan berpikir kritis peserta didik masih dominan berada pada kategori rendah. Hal ini bisa dilihat dari hasil menjawab soal pretest oleh peserta didik, dimana peserta didik cenderung menjawab soal pada tingkatan pertama kurang sesuai dengan teori, dan tingkatan kedua alasan menjawab kurang sesuai dengan teori serta tingkat keyakinan adalah yakin.

Dari data tersebut dapat disimpulkan bahwa kemampuan berpikir kritis peserta didik pada kelas XI MIPA 1 sebelum dan setelah diterapkan model pembelajaran tidak mengalami peningkatan secara signifikan.

Penelitian ini sejalan dengan penelitian yang dilakukan oleh Triyo Supriyatno, dkk (2020:1) yang menunjukkan bahwa kegiatan model pembelajaran inkuiri terbimbing lebih baik daripada model pembelajaran konvensional.

Demikian pula penelitian yang dilakukan oleh Dahlia, dkk (2016:5) yang mengemukakan bahwa hasil belajar peserta didik yang diajar menggunakan model pembelajaran inquiry training lebih tinggi daripada hasil belajar peserta dididk dengan menggunakan model pembelajaran konvensional.

Begitupun penelitian yang dilakukan oleh Hani Nur Azizah, dkk (2016:57) menunjukkan bahwa model pembelajaran konvensional dapat meningkatkan kemampuan berpikir kritis peserta didik dan peningkatan kemampuan berpikir kritis peserta didik dengan menggunakan model pembelajaran inkuiri terbimbing lebih baik daripada menggunakan model pembelajaran konvensional.

Yang membedakan penelitian ini dengan penelitian sebelumnya adalah pada penelitian sebelumnya digunakan model konvensional berbantuan media pembelajaran untuk mengetahui hasil belajar peserta didik sedangkan dalam penelitian ini menggunakan model pembelajaran konvensional yakni direct instruction dimana model pembelajaran ini dibandingkan dengan model pembelajaran inkuiri terbimbing berbantuan three tier test untuk mengetahui kemampuan berpikir kritis peserta didik.

\section{c. Perbedaan Kemampuan Berpikir Kritis Peserta Didik yang diajar Menggunakan Model Pembelajaran Guided Inquiry Berbantuan Three Tier Test dengan Model Pembelajaran Direct Instruction.}

Berdasarkan pengujian normalitas dengan menggunakan program IBM SPSS, Statistic 20 diperoleh nilai signifikan yang lebih besar dari 0,05 yaitu nilai pretest sebesar 0,200 dan posttest kelas 0,200 pada kolom Kolmogorov Smirnov, sehingga dapat disimpulkan bahwa nilai kemampuan berpikir kritis peserta didik sebelum dan setelah diberi perlakuan berdistribusi normal. Setelah dilakukan uji normalitas data dan data dinyatakan berdistribusi normal selanjutny dilakukan uji homogenitas data menggunakan uji $\mathrm{F}$ dari Hartley Person dan diperoleh nilai signifikansi 0,539 , nilai ini lebih besar daripada 0,05 , sehingga dapat disimpulkan bahwa kedua sampel memiliki varians yang sama atau homogen.

Hasil analisis uji hipotesis yang diperoleh dari kelas eksperimen dan kontrol dapat disajikan pada tabel 6. Hasil analisis uji t dua sampel independen sebagai berikut: 
Tabel 6. Hasil Analisis Uji T Dua Sample Independent

\begin{tabular}{|c|c|c|c|c|c|c|}
\hline \multicolumn{7}{|c|}{ Independent Samples Test } \\
\hline & & \multicolumn{2}{|c|}{$\begin{array}{l}\text { Levene's Test for } \\
\text { Equality of } \\
\text { Variances }\end{array}$} & \multicolumn{3}{|c|}{ t-test for Equality of Means } \\
\hline & & $\mathbf{F}$ & Sig. & $\mathbf{t}$ & Df & Sig. (2-tailed) \\
\hline $\begin{array}{c}\text { Kemampuan } \\
\text { Berpikir Kritis }\end{array}$ & $\begin{array}{c}\text { Equal } \\
\text { variances } \\
\text { assumed }\end{array}$ & .290 & .593 & 9.495 & 42 & .000 \\
\hline
\end{tabular}

Tabel 6 di atas menyajikan kesimpulan mengenai hipotesis yang diajukan, dapat dilihat dari hasil nilai signifikansi 2-tailed nilai equal variances assumed atau hasil uji parametrik diperoleh signifikansi 0,000 dimana nilai signifikansi tersebut lebih kecil dari 0,05. Sehingga dapat disimpulkan bahwa terdapat perbedaan kemampuan berpikir kritis peserta didik didik yang diajar dengan model pembelajaran inkuiri terbimbing (guided inquiry) berbantuan three tier test dan yang diajar dengan model pembelajaran direct instruction. Selain itu dari tabel di atas diperoleh nilai $t$ hitung sebesar 9.495 dimana nilai tersebut lebih besar nilai $\mathrm{t}$ tabel pada derajat kebebasan $\mathrm{df}=42$ dan signifikansi 0,809 adalah 1,68195. Berdasarkan kriteria penarikan kesimpulan yaitu jika $\mathrm{t}_{\text {tabel }}>\mathrm{t}_{\text {hitung }}$ maka $H_{0}$ ditolak. Jika $\mathrm{t}$ tabel $<\mathrm{t}$ hitung maka $H_{0}$ diterima, dengan taraf signifikan $\alpha=0,05$. Dari tabel hasil penelitian nilai $\mathrm{t}_{\text {tabel }}<\mathrm{t}_{\text {hitung }}$ maka $\mathrm{H}_{0}$ ditolak dan $\mathrm{H}_{1}$ diterima.

Data yang ditampilkan dalam penelitian ini meliputi nilai kemampuan berpikir kritis kelas eksperimen dan kelas kontrol untuk melihat ada tidaknya perbedaan kemampuan berpikir kritis peserta didik kelas eksperimen (yang diajar dengan model pembelajaran guided inquiry) dan kelas kontrol (menggunakan model pembelajaran direct instruction).

Perbedaan pokok analisis indikator kemampuan berpikir kritis yang dibandingkan dengan peserta didik dengan model pembelajaran direct instruction dan menggunakan model pembelajaran guided inquiry memiliki tingkat ratarata yang lebih tinggi dalam memberikan penjelasan sederhana, membangun keterampilan dasar, menarik kesimpulan dan membuat penjelasan lebih lanjut.

Peserta didik pada saat menjawab soal three tier test cenderung berada pada kategori tingkatan pertama menjawab benar, sesuai dengan teori, dan tingkatan kedua alasan menjawab kurang tepat dengan teori serta tingkat keyakinan yaitu yakin. Sedangkan hasil menjawab peserta didik pada kelas kontrol cenderung menjawab soal pada tingkatan pertama kurang sesuai dengan teori, dan tingkatan kedua alasan menjawab kurang sesuai dengan teori serta tingkat keyakinan masih tidak yakin.

Kemampuan berpikir kritis meliputi empat indikator yaitu, memberikan penjelasan sederhana, membangun keterampilan dasar, penarikan kesimpulan dan membuat penjelasan lebih lanjut. Berdasarkan soal berpikir kritis indikator memberikan penjelasan sederhana peserta didik dituntut untuk menjawab pertanyaan klarifikasi tentang sifat-sifat gelombang yang disajikan dalam soal dan mengajukan pertanyaan dari persamaan simpangan gelombang berjalan. Indikator membangun keterampilan dasar peserta didik dituntut untuk mempertimbangkan kredibilitas cepat rambat gelombang pada tali berdasarkan hasil percobaan dan mempertimbangkan hasil observasi besaran fisis gelombang stasioner pada tali. Indikator penarikan kesimpulan peserta didik dituntut untuk mendeduksi dan menilai deduksi untuk menentukan hubungan antara panjang gelombang dengan cepat rambat gelombang berdasarkan hasil percobaan hukum Melde. Indikator membuat penjelasan lebih lanjut peserta didik dituntut untuk mengidentifikasikan asumsi terkait gelombang longitudinal dan transversal.

Dengan menggunakan model inkuiri terbimbing ini pengembangan ranah kognitif peserta didik lebih terarah dan dalam kehidupan sehari-hari dapat diaplikasikan secara motorik. Keterampilan yang diperoleh melalui serangkaian proses sains membuat peserta didik aktif membangun pengetahuannya. Berbeda halnya dengan pembelajaran direct instruction, pengetahuan diajarkan dengan cara melatih peserta didik menghafal pengetahuan yang diberikan pendidik. Serangkaian kegiatan dilakukan secara instruksional tanpa memberi kesempatan peserta didik mencari sendiri pengetahuannya. Serangkaian kegiatan instruksional ini mengkondisikan pada situasi kelas yang diam, tanpa aktivitas peserta didik, tanpa kegiatan tanya jawab, peserta didik hanya memperhatikan penjelasan pendidik.

Kemampuan berpikir kritis peserta didik yang diajarkan dengan model pembelajaran guided inquiry menunjukan hasil yang lebih baik dibandingkan dengan pembelajaran direct instruction. Peserta didik mampu menjawab tes 
kemampuan berpikir kritis pada semua indikator kemampuan berpikir kritis dengan baik jika dibandingkan dengan pembelajaran konvensional yang memperoleh hasil kemampuan berpikir kritis yang lebih rendah. Dimana hal ini juga dilihat pada proses pembelajaran menggunakan model pembelajaran guided inquirymenunjukkan keaktifan peserta didik dalam memecahkan masalah. Sehingga penelitian ini menunjukkan bahwa terdapat perbedaan kemampuan berpikir kritis peserta didik yang diajar menggunakan model pembelajaran guided inquiry berbantuan three tier test dengan peserta didik yang diajar dengan model pembelajaran direct instruction.

Penelitian ini sejalan dengan penelitian oleh Siagian dan Panjaitan (2017:19) menyatakan bahwa ada pengaruh model pembelajaran inkuiri terbimbing dan pembelajaran konvensional terhadap kemampuan berpikir kritis peserta didik, dalam hal ini keterampilan berpikir kritis peserta didik yang diajarkan dengan model pembelajaran inkuiri terbimbing lebih baik dari pembelajaran konvensional.

Demikian pula penelitian Sitindaon, dkk (2017:129) mengemukakan bahwa kemampuan pemecahan masalah dan berpikir kritis peserta didik yang diajar dengan menggunakan model pembelajaran inkuiri terbimbing menggunakan media PhET lebih baik dibandingkan peserta didik yang diajar dengan model pembelajaran konvensional.

Begitupun penelitian yang dilakukan Iman, dkk (2017:52) menyatakan bahwa kemampuan berpikir kritis peserta didik yang diajarkan dengan metode inkuiri terbimbing memiliki nilai posttest lebih tinggi daripada yang diajarkan dengan metode konvensional.

Penelitian ini juga sejalan dengan penelitian yang dilakukan oleh Falahuddin, dkk (2016:92) yang menunjukkan bahwa model pembelajaran inkuiri terbimbing pada materi pengelolaan lingkungan berpengaruh terhadap kemampuan berpikir kritis peserta didik.

Penelitian ini juga didukung dengan beberapa penelitian terkait soal three tier test untuk mengetahui miskonsepsi peserta didik yaitu penelitian yang dilakukan oleh Novitasari, dkk menyimpulkan bahwa hasil pola jawaban peserta didik terdapat enam kriteria yaitu pemahaman konsep, miskonsepsi (+), miskonsepsi (-), miskonsepsi, menebak / kurang percaya diri / keberuntungan, dan tidak memahami konsep yang digunakan untuk mendiagnosis pemahaman peserta didik dalam mengukur kemampuan berpikir tingkat tinggi (HOTS) yang terintegrasi dengan dimensi pengetahuan faktual, konseptual dan procedural (Novitasari,dkk, 2019).
Perbedaan penelitian ini dengan penelitian sebelumnya adalah, pada hasil penelitian sebelumnya digunakan model pembelajaran inkuiri terbimbing untuk mengetahui pengaruh model pembelajaran terhadap kemampuan berpikir kritis peserta didik menunjukkan bahwa pada aspek inference atau memberikan kesimpulan tidak mengalami peningkatan sedangkan dalam penelitian ini implementasi model pembelajaran inkuiri terbimbing berbantuan three tiertest terhadap kemampuan berpikir kritis peserta didik mengalami peningkatan di semua indikator.

\section{Kesimpulan}

Terdapat perbedaan kemampuan berpikir kritis peserta didik yang diajar menggunakan model pembelajaran guided inquiry berbantuan three tier test lebih tinggi daripada kelas yang diajar dengan model direct instruction. Hal ini dapat dilihat dari kecenderungan peserta didik dalam menjawab soal pada tingkatan pertama yaitu menjawab soal sesuai dengan konsep yang ada, sesuai dengan teori atau jawaban benar dan tepat, dan pada tingkatan kedua alasan menjawab sesuai dengan teori serta tingkatan ketiga tingkat keyakinan peserta didik yaitu yakin. Sedangkan pada kelas yang tidak diajar dengan model pembelajaran guided inquiry cenderung menjawab soal pada tingkatan pertama kurang sesuai dengan teori, dan tingkatan kedua alasan menjawab kurang sesuai dengan teori serta tingkat keyakinan adalah yakin.

\section{Referensi}

Arikunto, Suharsimi. (2006). Prosedur Penelitian Suatu Pendekatan Praktik. Jakarta: PT. Rineka Cipta.

Fajri, Saminan Nurul, dkk. (2016). "Peningkatan Keterampilan Berpikir Kritis Dan Sikap Ilmiah Peserta didik Dengan Menggunakan Model Cooperative Inquiry Labs (Cil) Pada Materi Suhu Dan Kalor", Jurnal Pendidikan Sains Indonesia, 04.(01), 188.

Falahudin,Irham, dkk. (2016). Pengaruh Model Pembelajaran Inkuiri Terbimbing Terhadap Kemampuan Berpikir Kritis Peserta didik Pada Pembelajaran Materi Pengelolaan Lingkungan Di Smp Negeri 2 Tanjung Lago, Kabupaten Banyuasin. Jurnal Bioilmi, 2. (2), 92-101.

Fathurrohman, Muhammad. (2015). Model-Model Pembelajaran Inovatif. Jogjakarta: Ar-ruzz Media.

Hamidah, Luluk. 2018. Higher Order Thinking Skills: Seni Melatih Kemampuan Berpikir 
Tingkat Tinggi. Temanggung: Desa Pustaka Indonesia.

Hunaepi,dkk. 2014. Model Pembelajaran langsung Teori dan Praktik. Mataram: Duta Pustaka Ilmu.

Ibrahim. Juni (2017). Perpaduan Model Pembelajaran Aktif Konvensional (Ceramah) Dengan Kooperatif (Make - A Match) Untuk Meningkatkan Hasil Belajar Pendidikan Kewarganegaraan.Jurnal Ilmu Pendidikan Sosial, sains, dan Humaniora, 3. (2), 202.

Iman, Rusulun, dkk. (2017). Meningkatkan Kemampuan Berpikir Kritis Peserta didik dengan Model Inkuiri Terbimbing pada Materi Pesawat Sederhana. (Jurnal Pendidikan Sains Indonesia, 05(01), 52.

Iskandar, Akbar dan Muhammad Rizal. (Desember 2017). Analisis Kualitas Soal di Perpendidikan tinggi Berbasis Aplikasi Tap.Jurnal Penelitian dan Evaluasi Pendidikan, 21 (2), 12-23.

Jusman, dkk, Maret 2020. Perbandingan Pemahaman Translasi Antara Model Pembelajaran Inkuiri Terbimbing Dan Inkuiri Bebas Termodifikasi Mahasiswa Pendidikan Fisika Uin Alauddin Makassar, Jurnal Pendidikan Fisika Vol. 8 No. 1, , h.25.

Kementerian Agama Republik Indonesia. [t.th]. AlQur'an dan Terjemahan. Surabaya: Fajar Mulya.

Lismaya, Lilis. 2019. Berpikir kritis dan PBL (Problem Based Learning). Surabaya:Media Sahabat cendekia.

Mandagi, Mieke dan Arintje Sundah. 2019. Model dan Rancangan Pembelajaran. Malang: Seribu Bintang.

Maulini, Septi, dkk. September (2016). The Three Tier-Test untuk Mengungkap Kuantitas Peserta Didik pang Miskonsepsi Pada Konsep Gaya Pegas".Jurnal Ilmu Pendidikan Fisika. 1 (2), 42-44.

Niana, Rulita, dkk, (2016). The Application of Guided Inquiry Model On Physic Learning to Improve Scientific Attitude and Students Analysis Ability, (Journal ICTTE International Conference on Teacher Training an education), 2 (1), 605.

Nisa, E K, dkk. (2018). "Effectiveness of Guided Inquiry Learning Model To Improvestudents' Critical Thinking Skills At
Senior High School" Jurnal Fisika: Conf. Seri. Universitas Negeri Surabaya.

Nurhasan, Ropií, dkk, Juli 2019). Guided Inquiry Scratch Increase Students Critical Thinking Skills on the Linear Motion Concept: Can it be?, JPPPI, 5 (1),63.

Octavia, Shilphy. 2020. Model-model Pembelajaran. Yogyakarta: Budi Utama.

Partah, I Nengah. 2017. Model Pembelajaran Inkuiri: Refleksi, Membangun Pertanyaan, Penghalusan Pengetahuan, Internalisasi Pengetahuan. (Cet. I: Malang; Universitas Negeri Malang Press.

Sari,Novita Wayan Ni, dkk. 2019. Mengembangkan dan Memvalidasi The Three Tier Diagnostic Test Based 'Higher Order Thinking Skills 'Instrument. Thesis. Universitas Lampung.

Sanjaya, Wina. 2006. Strategi Pembelajaran. Jakarta: Kencana Prenada Media Group.

Santrock, W, John. 2007. Psikologi Pendidikan. cet-1; Jakarta: Prenada Media Group.

Serenica, Christinsenia, dkk. Jan. - Feb (2018) Influence of Guided Inquiry Learning Model to Critical Thinking Skills. IOSR Journal of Research \& Method in Education, 8(1).

Siagin,Asister dan Panjaitan Muktar. (2017). Perbedaan Model Pembelajaran Inkuiri terbimbing dan Pembelajaran Konvensional terhadap Kemampuan Berpikir Kritis Peserta didik SMA . Jurnal INPAFI,.5 (1), 19-26.

Siregar, Syofian. 2015. Statistik Parametrik Untuk Penelitian Kuantitatif. Jakarta: PT Bumi Aksara.

Sitindaon, Fitriani Sondang, dkk. (2017). The Effect of Guided Inquiry Learning Using PhET Media on Students' Problem Solving Skill and Critical Thinking. Journal of education and Practice, 8 (2), 129.1

Yazidi, Akhmad. (2014). Memahami Model-Model Pembelajaran Dalam Kurikulum2013 (The Understanding Of Model Of Teaching In Curriculum 2013), 4 (1), 1-146. 